\title{
A CRIAÇÃO DA DIOCESE DE CURITIBA E O PROCESSO DE DIOCESANIZAÇ̃̃O PÓS-PADROADO
}

\author{
The Creation of Curitiba's Diocese and the Post-Patronate Process of \\ Diocesanization
}

\section{Resumo:}

Marcia Regina de Oliveira Lupion ${ }^{1}$

Este artigo objetiva apresentar a criação da diocese de Curitiba no ano de 1892 como um desdobramento do processo de diocesanização, ou seja, da criação extensiva de dioceses pela Igreja Católica pelo Brasil ocorrido no pós-Proclamação da República. O fenômeno da diocesanização é visto ainda como uma reação da Igreja Católica em se reorganizar sobre a autogestão a que foi submetida a partir sobretudo do Decreto 119-A de 1890, documento responsável pela extinção do Padroado que enfatiza o caráter laico do governo republicano. Vários obras e autores contribuíram para a elaboração da discussão aqui pretendida como o livro produzido pelo hoje Bispo Emérito de Curitiba Dom Pedro Antônio Marchetti Fedalto, "História da Igreja no Paraná" de 2014; a obra da geógrafa Zeny Rosendahl "Primeiro a obrigação, depois a devoção" publicado em 2012 e a tese de Maurício de Aquino (2012) sobre a criação da diocese de Botucatu em 1908, trabalho em que o conceito de diocesanização foi cunhado. Em todos os sentidos a discussão presente nesse artigo visa contribuir para os estudos acerca da História da Igreja Católica no Paraná e das Religiões e religiosidades como um todo.

Palavras-chave: Diocese de Curitiba. Pós-Padroado. Estado Laico. Diocesanização.

\begin{abstract}
:
This article seeks to present the creation of Curitiba's diocese in 1892 as an unfolding of the process of diocesanization, that is to say the extensive creation of dioceses by the Catholic Church in Brazil after the Proclamation of the Republic. The diocesanization phenomenon is still seen as a reaction of the Catholic Church in reorganizing itself under the self-administration to which it became submitted, especially following Decree 119-A of 1890, the document responsible for the extinction of the Patronate, which emphasized the secular character of the republican government. Several works and authors contributed to the discussion presented here, such as: the book produced in 2014 by (the now) Bishop Emeritus of Curitiba, Dom Pedro Antônio Marchetti Fedalto, "History of the Church in Paraná"; the work of philosopher Zeny Rosendahl, "The obligation, then the devotion" published in 2012; and the 2012 thesis by Maurício de Aquino on the 1908 creation of the diocese of Botucatu, where the concept of diocesanization was coined. In all senses, the discussion presented in this article aims to contribute to the History of the Catholic Church in Paraná, as well as and Religiosity and Religions as a whole.
\end{abstract}

Keywords: Curitiba's Diocese. Post-Patronate. Laic State. Diocesanization.

\footnotetext{
${ }^{1}$ Graduada em História, Mestre em História Social e Doutoranda em História Cultural com ênfase em História do catolicismo no Brasil - Universidade Estadual de Maringá. E-mail: mrolupion2@ gmail.com
} 


\section{BRASIL, 1889: ESTADO LAICO E IGREJA CATÓLICA}

Em 11 de março de 1856 Zacarias de Góes e Vasconcelos, presidente da Província do Paraná, envia um relatório a seus superiores no qual informa sobre a delicada situação religiosa no Estado. Segundo ele, a de falta de sacerdotes para o ministério dos sacramentos e as péssimas condições das construções religiosas são fatores que contribuem decisivamente para a fragilidade da instituição na região (FEDALTO, 2014, p. 111).

Quase trinta anos depois outro Presidente da Província, o Dr. José Pedrosa, em relatório enviado a Assembleia Legislativa paranaense em 16 de fevereiro de 1881 faz eco aos pedidos de Zacarias de Góes e Vasconcelos. Escreve ele sobre o triste estado da religião no Paraná e destaca como prováveis motivos para essa infelicidade o pouco zelo de alguns padres para com o culto público e o indiferentismo do povo pela causa da religião (FEDALTO, 2014, p. 111). E, em relatório datado de 16 de janeiro de 1882, ou seja, menos de um ano depois do relatório de José Pereira, o vice-presidente da Província do Paraná, José Antônio Vaz de Carvalho retoma a temática e escreve à Assembleia Legislativa as seguintes palavras:

[...] o estado religioso da Província não é satisfatório e que ao se ver o abandono, em que por aqui anda o culto, quase que se acredita nos célebres cálculos de um matemático escocês que, para época não distante, marcou o desaparecimento da religião de Cristo, a menos que se repita a Encarnação do Verbo Divino. As igrejas, em obras que nunca mais acabam, existem quase todas em um estado vizinho de indecência. E o povo, como que para furtar-se a tão triste espetáculo, deixa de frequenta-las e, assim se vai aos poucos a crença de nossos maiores (FEDALTO, 2014, p. 112).

Em livro sobre a história da Igreja Católica no Paraná publicado em 2014 e utilizado como guia didático nos seminários espalhados pelo Estado, Dom Pedro Antônio Marchetti Fedalto atual bispo emérito de Curitiba, explica que todos esses relatórios tinham por objetivo "pedir remédio para esse estado de desmantelamento que dificulta os exercícios da religião, tão necessários para moralizar o povo e adoçar seus costumes" (FEDALTO, 2014, p. 111). Ou seja, para os membros do governo provincial a religião era um elemento necessário para a formação da sociedade paranaense, mas, dadas as condições da religião católica na região, não seria possível contar com o apoio dessa instituição caso não houvesse incentivo e promoção do governo junto à mesma. 
Não contavam, porém, os presidentes da província paranaense com a mudança na forma do regime político brasileiro ocorrido em 1889. Fato que trouxe novas perspectivas para o papel da religião católica que de conselheira governamental passou a numerar como mais uma dentre as demais instituições que fazem parte de um país republicano e pretensamente laico. Com o fim da relação de quase quatrocentos anos com o governo, a Igreja Católica iniciou-se na autogestão de seus bens materiais e simbólicos sendo que o maior investimento da instituição foi, exatamente, fortalecer seu aparato estrutural aumentando significativamente o equipamento material por meio da criação de bispados pelo país, fenômeno que foi batizado por Maurício de Aquino como diocesanização (2012).

Os parágrafos acima introduzem a questão debatida neste artigo que é a criação da diocese de Curitiba, Estado do Paraná, como parte da estratégia de autogestão da Igreja Católica a partir da extinção do Regime do Padroado em 1890 por meio do Decreto 119-A. A criação extensiva de dioceses pelo território brasileiro a partir dessa data tem sido vista como um movimento que fez frente à nova postura governamental pautada na laicidade adotada pelo recém-criado Estado Republicano em 1889. Nesse sentido, a criação da diocese paranaense atenderia tanto a nova organização gestora da Igreja Católica quanto aos interesses dos governantes paranaenses que viam na organização do catolicismo a possibilidade de moralizar a sociedade e adoçar os costumes, seja qual for o significado dessa expressão cujo sentido não foi explicitado por Fedalto (2014, p. 111).

Esse estudo ${ }^{2}$ foi feito considerando obras e autores que discorrem sobre a temática privilegiando a produção interdisciplinar para a compreensão do objeto. Nessa cadência, a ideia de criação de dioceses como uma estratégia da Igreja Católica frente a sua nova condição de autogestora de seu equipamento material e simbólico foi pensada a partir do proposto por Maurício de Aquino (2012) e Zeny Rosendahl (2012). Em sua tese, Aquino procura situar a

\footnotetext{
${ }^{2}$ Originalmente o estudo sobre a criação da Diocese de Curitiba foi realizando para colaborar com informaç̃̃es que pudessem contribuir para uma versão do contexto no qual foi criada a também diocese de Maringá no ano de 1956. O histórico do estabelecimento desses equipamentos católicos visava contribuir para compreender o contexto no qual Bernardo Abel Alphonse Cnudde, padre conhecido por praticar curas e exorcismos em Maringá, viveu e desenvolveu uma prática religiosa peculiar e que, dadas suas formas operativas, tornou-se objeto de uma pesquisa doutoral ainda inconclusa. Compreender a criação extensiva de dioceses e arquidioceses pelo país sobretudo no pós-Proclamação da República permitiu ter uma visão panorâmica da prática de Bernardo. Visão esta que permitiu compreender a forma como a instituição de pertencimento do padre operava suas ações frente aos espaços físicos considerados aptos a serem ocupados notadamente no que concerne aos municípios recém fundados como foi o caso de Maringá em 1947.
} 
criação da diocese de Botucatu no ano de 1908 como parte da estratégia que foi conceituada por ele como diocesanização da Igreja Católica. Ou seja, o movimento promovido pela instituição Católica de expansão do capital simbólico por meio do aumento de seu equipamento físico objetivava dar mais visibilidade e espaço à instituição numa sociedade que se mostrava aberta a outras religiões sobretudo após o Decreto 119-A de 1890 que garantia a liberdade de culto no país. O conceito de diocesanização foi explicitado por Aquino como sendo "[...] um fenômeno de criação de dioceses que rearticulou lugares físicos, políticos e discursivos em dimensões sociopolíticas e religiosas, em sintonia com as determinações da Cúria Romana [...]” (AQUINO, 2012, p. 82, nota 163).

Já Rosendhal prioriza o estudo sobre a criação de espaços religiosos pelo Brasil desde 1551 até o ano 2005 e vê, na criação extensiva de dioceses sobretudo após 1889 uma estratégia utilizada pela Igreja Católica para demarcar seu poder sobre o território brasileiro. Nesse sentido, atrelado ao fenômeno da diocesanização está o conceito de territorialidade criado por Zeny Rosendahl (2012). Se por diocesanização compreende-se a expansão, domínio e manutenção do capital simbólico cristão-católico, territorialidade "significa o conjunto de práticas desenvolvido por instituições ou grupos no sentido de controlar dado território" (ROSENDAHL, 2012, p. 22). Ou seja, ambos os conceitos são complementares pois buscam compreender e explicar a estratégia encontrada pela Igreja católica no Brasil em fins do século $\mathrm{XIX}$ até meados do XX frente ao projeto republicano de um estado laico.

Datada de 1892 a criação da diocese de Curitiba encontra-se inserida nesse momento histórico e foi concebida, portanto, como parte dessa estratégia de fortalecimento da Igreja Católica frente a nova realidade que se descortinava no limiar do século XX. Essa hipótese foi levantada considerando uma série de obras que abordam a temática sobre os caminhos tomados pela Igreja Católica quando a instituição foi confrontada com a realidade de um estado republicano em 1889. Com essa bibliografia pretendemos elaborar um quadro no qual seja possível visualizar um sistema de relações cuja imagem permita a reflexão sobre as condições políticas, econômicas, simbólicas e regionais presentes no contexto em que a diocese paranaense foi fundada. Afinal, concordamos com Certeau quando o estudioso diz que:

El trabajo histórico, hasta em su aspecto de erudición, no se limita por tanto a reunir objetos hallados. Sobre todo tiene que ver con su correlación. Al combinar la multiplicación de las huellas (papel de erudición) y la invención 
de hipótesis o pertinencias (papel de la teoría), instaura un sistema de relaciones. De ese modo produce el conocimiento de un pasado, es decir, de una unidad (biográfica, ideológica, económica, etc.) pretérita (precisamente cuando exiten "restos", tomados en otros sistemas) (CERTEAU, 2007, p. 54, grifos do autor).

Nesse sentido, as obras utilizadas como referência para a hipótese levantada foram compreendidas como documentos cujos dados, quando entrelaçados, se combinam e se relacionam de forma a dar um sentido para a ocorrência da criação da diocese curitibana em 1892. Com isso não pretendemos exumar um passado tal qual o ocorrido, mas, promover uma operação historiográfica cujo produto ou conhecimento permita compreender o processo de criação da diocese paranaense como parte da estratégia utilizada pela Igreja Católica para expandir e demarcar seu campo de ação em âmbito nacional com o fim do Regime do Padroado em 1890.

\section{AINDA BRASIL 1889...}

Além dos motivos apresentados nos relatórios dos presidentes provinciais e vice, Dom Fedalto (2014) cita outros elementos dificultares à prática da religião católica no Paraná provincial sobretudo em relação ao clero. Segundo o prelado, o fato de padres e missionários darem maus exemplos vivendo em concubinato contrariando os votos de observância do celibato; a própria recusa da Igreja em abolir o celibato; padres que praticavam o ministério incorreto das missas e das confissões; padres avaros e, principalmente, número insuficiente de sacerdotes para atender às demandas do Estado paranaense são outros motivos pelos quais a criação da diocese tornou-se uma ação necessária naquele momento. Assim, quando a Igreja Católica viu na criação de dioceses a estratégia ideal para manter e estender seu poder junto à população e fazer frente às religiões que passaram a ser reconhecidas pelo governo laico, transformar a paróquia curitibana em diocese tornou uma medida necessária em algo plenamente concretizável.

Fazem parte ainda dos motivos listados como empecilhos à prática clerical considerada ideal, a complexidade em incutir nos indígenas a cultura religiosa cristã; a distância espacial entre padres e sedes episcopais e, entre os próprios padres; a falta de retiros espirituais e 
formação pastoral em seminários e, por fim, a oposição entre os párocos em colocar em prática as orientações vindas dos bispos (FEDALTO, 2014, p. 112-114).

Em relação aos leigos, o bispo informa que havia muitos fiéis que levavam uma vida cristã exemplar sendo fervorosos nos sacramentos, outros, porém, viviam em concubinato e muitas vezes adquiriam riquezas de forma ilícita, outros ainda cometiam adultério com as escravas e maltratavam a escravaria em geral (FEDALTO, 2014, p. 115, 116). No geral, no entanto, "a participação do povo era mais na religiosidade popular, nas procissões, levantamento de mastros dos padroeiros. A presença dos padres não era tão exigida. Os leigos promoviam a devoção popular" (FEDALTO, 2014, p. 116).

Mas, não somente elementos regionais são citados por Dom Fedalto como motivos que justificam a criação da diocese paranaense. Cita o bispo emérito a crise do clero estava interligada também a questões que se encontram entrelaçadas às demandas histórico-nacionais e internacionais do período dentre os quais se destacam:

O positivismo, o regalismo, o iluminismo, a maçonaria influíram negativamente na prática da vida espiritual, sacramental. Muitos no litoral paranaense, em Curitiba, São José dos Pinhais, Guarapuava e Palmas levavam uma vida religiosa apática, imbuídos de ideias maçônicas, e sem uma postura ética e moral condizentes com a lei cristã (FEDALTO, 2014, p. 116).

Diante da situação descrita Dom Fedalto conclui que a vida religiosa católica no Paraná e no Brasil em fins do Império encontrava-se com uma estrutura debilitada tanto pelos acontecimentos políticos, notadamente relativos ao poder da maçonaria e do positivismo nos altos escalões do poder, quanto pela falta de padres e excesso de escândalos praticados por muitos deles. Segundo ele ainda, o fato de a população viver uma religiosidade popular que prescindia da presença do padre uma vez que a participação do povo se dava na forma de procissões e levantamento de mastros dos padroeiros o fato é que na maior parte do tempo, "o povo vivia abandonado espiritualmente, sem nenhuma formação religiosa e cultura cristã" (FEDALDO, 2014, p. 116). Todos esses elementos, portanto, são parte do quadro estadual e nacional sobre o qual a diocese de Curitiba foi criada.

Há que se fazer jus ao fato de que a situação do clero paranaense pouco difere do clero nacional. Vejamos o caso paulista uma vez que a maioria dos clérigos que vieram para o Paraná 
eram oriundos de São Paulo. Dom Fedalto sistematiza a condição do clero paulista como havendo entre seus membros muitos candidatos ao sacerdócio que o faziam de fato pelo amor a Deus e o faziam de forma edificante. Mas, esse comportamento não era regra. Grassava entre os seminaristas e sacerdotes mais jovens aqueles que se entregavam ao clericato por imposição da família, para conseguir um emprego, pela má seleção dos candidatos ou por serem fazendeiros. Considera ele que muitos davam mau exemplo perante a comunidade pois eram, além de mal preparados na teologia e liturgia, dados a rixas, ganância e não observância do celibato (FEDALTO, 2014, p. 110).

Diante desse quadro em 1888 Dom Lino Deodato Rodrigues de Carvalho (1826-1894), bispo da diocese de São Paulo, promove o Sínodo Diocesano em conformidade com as recomendações do papa Pio IX (ARQUIDIOCESE DE SÃO PAULO, 2019) no que concerne à reforma clerical cujo sentido era coibir o mau exemplo dos padres e recomendava,

[...] o celibato, o uso da tonsura, da batina, evitar o comércio e a simonia. Proibia os bailes, os teatros, as touradas e as cavalgadas, o jogo, a caça, o exercício da medicina, da advocacia. Determina o estudo da teologia dogmática, da moral, da liturgia, o culto a Maria, aos Santos, a explicação pormenorizada da doutrina católica, a prática da pastoral, o dever da missa e recitação da Liturgia das Horas, a obrigatoriedade da residência na paróquia (FEDALTO, 2014, p. 110).

Parte do episcopado de Dom Lino aconteceu já no período republicano e foram diversas as contendas entre o bispo e o governo descritas no histórico da arquidiocese de São Paulo, algumas delas tendo o bispo saído vitorioso, como no caso em que o Estado mandou demolir a igreja do Colégio dos Jesuítas como se esta fosse uma propriedade nacional quando não o era recebendo a Mitra Diocesana ganho de causa. Já noutro exemplo a Mitra não obteve sucesso quanto solicitou o retorno do produto das loterias que havia sido estabelecido por Dom Pedro II como pertencente a diocese. Nesse caso os esforços foram vãos e a quantia que estava destinada ao auxílio na construção da Catedral foi depositada no Tesouro Nacional e revertida em financiamento para uma escola normal "já que o Estado estava separado da Igreja" (ARQUIDIOCESE DE SÃO PAULO, 2019). Dois exemplos que demonstram conflitos e rearranjos sobre os quais Estado e Igreja Católica foram submetidos com a ascensão da República em 1889. 
A discussão acima revela a importância da mudança no regime político e governamental ocorrido no Brasil com o advento da República em 1889 para a efetivação do movimento que levou a criação da diocese de Curitiba e pouco desenvolvido na obra de Dom Fedalto. Embora o prelado faça referência à reforma do clero, ao fim do Padroado, à Questão Religiosa e a relação entre o Estado e a maçonaria como concorrentes para a reforma da instituição, não há aprofundamento das temáticas que são apresentadas em breves parágrafos em sua obra.

Assim, para uma melhor compreensão acerca da criação da diocese paranaense é salutar conhecer o seu envolvimento numa dinâmica de maior alcance que foi a reordenação do Estado brasileiro e da Igreja Católica no Brasil em fins do século XIX e que se encontra no primeiro momento do cenário que levou a instituição a se organizar a partir da autogestão. Vejamos o que diz Aquino sobre esse momento e os desdobramentos promovidos pela Igreja Católica frente à emergente sociedade laica autorizada pelo governo:

\begin{abstract}
Marco da história política brasileira, a instauração da república em 15 de novembro de 1889 resultou na promulgação do decreto $119-\mathrm{A}$, de 07 de janeiro de 1890, responsável pela extinção do padroado, fazendo desta última data um marco cronológico referencial na história das religiões no Brasil, com profundos efeitos sobre o catolicismo devocional e institucional até então considerado religião oficial do Estado com todas as prerrogativas decorrentes dessa condição. Assim, o dia 07 de janeiro de 1890 inaugurou a Era PósPadroado da história brasileira sinalizada pela emergência do Estado laico e pela promulgação da liberdade religiosa (AQUINO, 2013, p. 120).
\end{abstract}

O fim do Padroado, contudo, não é um efeito exclusivo do Decreto 119-A. Concorreram para sua extinção acontecimentos anteriores sobretudo o movimento conhecido como Questão Religiosa ocorrida entre 1872 e 1875 envolvendo o papa Pio IX, o Imperador Dom Pedro II, os bispos do Brasil e o combate à maçonaria e à modernidade laica. O estopim que principiou a cisão foi dado pelas propostas presentes no sumário Syllabus Errorum e pela Encíclica Quanta Cura emitidos em 1864 e levados a cabo conjuntamente com orientações oriundas do Concílio Vaticano I (1869-1870) e o movimento de romanização e fortalecimento do poder papal oriundos desse evento no qual se destaca o dogma acerca da infalibilidade do pontífice. Além disso, na ocasião da Questão Religiosa o arcebispado da Bahia e os bispos brasileiros das dioceses de Mariana, Fortaleza, Diamantina, Porto Alegre e da Prelazia de Goiás mostraram-se 
solidários e obedientes ao papa e não ao Imperador, o que gerou ainda mais conflitos entre as duas esferas de poder.

O episódio da Questão Religiosa foi estudo em profundidade pelo historiador Dievani Vital e assim sintetizado:

\begin{abstract}
Mas afinal, qual seria então o motivo dessa hostilidade da Igreja brasileira para com a maçonaria já que ambas instituições tinham relações muito próximas por conta de seus membros? Para nos aprofundarmos na resposta à essa pergunta devemos nos lembrar que a maçonaria enquanto sociedade secreta encontrava-se condenada pelo Syllabus, enumeração sumária lançada em 1864 por Pio IX que continha os oitenta "erros" da sociedade moderna da época, segundo a autoridade da Igreja. Ou seja, a instituição de caráter laico também era entendida como um erro dos tempos modernos. Como já apontamos, os bispos reformadores brasileiros orientaram suas ações de modo a atender às aspirações universalistas de Roma, expressas através do Syllabus e da Encíclica Quanta Cura, ambos documentos papais ratificados pelo I Concílio Vaticano em reação aos novos tempos da modernidade, definidos pelas conquistas do pensamento liberal ilustrado da Revolução Francesa. O ato de expulsão do padre Almeida Martins, após o discurso em loja maçônica em março de 1872, foi assim tomado como ofensivo pela instituição de tradições iluministas atuante no Brasil. Logo em seguida viriam as medidas dos bispos (VITAL, 2015, p. 135).
\end{abstract}

Sendo o Imperador praticante da maçonaria assim como intelectuais e diversos clérigos brasileiros, o movimento promovido por Pio IX principiou o início de rachaduras na instituição do padroado uma vez que tal estrutura, naquele momento, já não atendia aos interesses de uma elite que se constituía sob os ideais iluministas e modernizantes e que assumia, cada vez mais, os rumos da política e da condução social brasileira ${ }^{3}$ para além do poder religioso.

\footnotetext{
${ }^{3}$ A ruptura entre Estado e Igreja, no entanto, não foi tão profunda como parecia a princípio. Como tal discussão extrapola os marcos desse artigo e já foi estuda à exaustão por diversos autores, sugerimos a leitura dos trabalhos de GOMES, Edgar da Silva. A separação Estado-Igreja no Brasil (1890): uma análise da pastoral coletiva do episcopado brasileiro ao Marechal Deodoro da Fonseca. 2006. 242 f. Dissertação (Mestrado em Teologia Dogmática). Centro Universitário Assunção - Pontifícia Universidade de Teologia Nossa Senhora da Assunção. São Paulo, 2006. Disponível em < http://livros01.livrosgratis.com.br/cp023647.pdf >. Acesso 29 jan. 2019; MARCHI, Euclides. A igreja e o Estado: a construção da concórdia. Estudos hibero-americanos. PUCRS, v. 19, n. 02, dez. 1993. p. 65-97; AZEVEDO, Dermi. A Igreja Católica e seu papel político no Brasil. ESTUDOS AVANÇADOS, 18 (52), 2004. p. 109-120; AZEVEDO, Thales de. O catolicismo como religião do regalismo no Brasil. In: __. A religião civil brasileira: um instrumento político. Petrópolis: Vozes, 1981. p. 43-52; AZEVEDO, Thales de. Primeira República: positivismo declinante e nacionalismos espiritualistas. In: . A religião civil brasileira: um instrumento político. Petrópolis: Vozes, 1981. p. 69-78; AZEVEDO, Thales de. Nos anos 30: a Lei e o Estado "sob a proteção de Deus". In: A religião civil brasileira: um instrumento político. Petrópolis: Vozes, 1981. p. 79-87; AZZI, Riolando. O início da restauração católica no Brasil 1920-1930. In: SOUZA, Rogério Luiz de; OTTO, Clarice. (Orgs.). Faces do catolicismo. Florianópolis, SC: Editora Insular, 2008. p. 61-89.
} 
Os efeitos das mudanças promovidas pela laicização do Estado não tardaram a ser sentidos. Houve, como citado nos dois exemplos envolvendo Dom Lino, reações por parte do clericato brasileiro. Estes, ao mesmo tempo em que se viram libertos das limitações impostas pelo Padroado pelo Decreto 119-A e amparados pelo movimento de romanização determinado pelo Concílio Vaticano I (1869-1870) viram também, em princípio, seu poder religioso ser excluído das decisões políticas pelo governo republicano recém constituído e principalmente pelos ideais iluministas que o acompanharam.

Considerando apenas a letra do Decreto 119-A de 1890 tem-se a impressão de que a separação Estado e Igreja se deu forma definitiva tanto institucional quanto culturalmente, contudo, a realidade posterior ao Decreto mostrou que a Igreja se reorganizou perante a nova realidade por meio da criação de dioceses como tem sido explicitado nesse artigo mas, essa não foi a única forma utilizada pela Igreja Católica para demarcar seu espaço na sociedade. Por exemplo, entre 1891 e 1920 em Belo Horizonte foram promovidos protestos quanto a retirada do ensino religioso das escolas públicas e, os governos belo-horizontinos desse período pressionados por grupos católicas leigos orientados por sacerdotes locais acabaram, na última data, por ceder à demanda. Assim, o ensino religioso, que no período ora estava presente no currículo ora não, retornou definitivamente para os colégios (MICELI, 1985, p. 70). Nesse sentido, aquilo que parecia uma separação efetiva entre Estado e Igreja Católica mostrou-se ao longo do tempo uma reacomodação de interesses, fato que foi assim explicitado por Miceli:

\footnotetext{
A separação não significou uma ruptura com os grupos dirigentes locais nem suscitou um redirecionamento das políticas e dos investimentos da igreja com vistas a ampliar seu público fora das classes dirigentes ou a estabelecer alguma forma de atendimento às demandas dos setores sociais subalternos. As figuraschaves na condução da política eclesiástica destinada ao público interno (a saber os grupos dirigentes) passaram a ser aqueles bispos "empresários" que se mostraram bem-sucedidos na montagem de alianças com o poder local oligárquico (Miceli, 1985, p. 45).
}

Institucionalmente podemos estabelecer como a reação mais expressiva e imediata da nova relação entre Igreja Católica e Estado a publicação da Pastoral Coletiva de abril de 1890 (2019). Nesse documento o episcopado se posicionou frente ao Decreto 119-A, normatização que proibiu a intervenção do governo Federal e Estadual na vida religiosa e consagrou a plena liberdade de cultos no país além de extinguir o Padroado. Além disso, o Decreto reconheceu 
todas as igrejas e confissões religiosas como entidades jurídicas e, portanto, senhoras da administração de seus bens e edifícios (BRASIL. DECRETO 119-A, 1890).

Dom Odilão de Moura descreve as mudanças provocadas pelo decreto acima e por outros que o sucederam da seguinte forma:

Inegavelmente, o Decreto revolucionário favoreceu a Igreja ao libertá-la do cárcere de ouro. Mas este Decreto, os outros que após foram publicados e os dispositivos constitucionais de 1891 relativos à liberdade religiosa não respeitaram integralmente as exigências do Direito Natural a respeito desta liberdade. A obrigatoriedade do casamento civil antes do religioso, a laicização plena dos cemitérios, a inelegibilidade dos clérigos, a negação do direito de votas aos religiosos, a proibição do ensino religioso nas escolas públicas, a conservação da legislação sobre os bens de "mão morta" evidenciam que as disposições legais sobre a liberdade religiosa não se adequavam bem à justiça natural, que vinham carregadas de preconceitos contra a Igreja (MOURA, 1978, p. 34. Grifos do autor).

A Pastoral Coletiva de 1890 é um dos documentos que mostra como a Igreja passou a concentrar toda sua atenção na defesa e manutenção da sobrevivência do catolicismo. Foi destinada ao clero, aos fiéis e ao Marechal Deodoro da Fonseca, Chefe do governo provisório e teve por objetivo colocar esses grupos, principalmente os dois primeiros, a par da situação em que a Igreja se encontrava perante o governo estabelecido.

A Pastoral Coletiva acenou com a intenção de se manter unidos os poderes civil e eclesiástico de tradição três vezes secular no país, mas a realidade indicava outro caminho a ser seguido, foi necessário repensar a situação da Igreja e sua nova configuração jurídica no país, eclesiástica pois entre tantas outras atribuições a elite assumiu prerrogativas que estiveram nas mãos do Imperador desde a instalação do primeiro bispado no como por exemplo, indicar os nomes dos futuros bispos e a organização de novas dioceses com patrimônio próprio, sem nenhuma subvenção do governo federal ou dos governos estaduais, apesar dos arranjos que o poder civil teve que fazer com o catolicismo para se adaptar as exigências do poder central. Note se que esta situação da ligação entre os poderes temporal e espiritual mais uma vez se manteve por pura conveniência, com isto, em matéria de ensino, o catolicismo não ficou desamparado da subvenção, e, como estamos tratando neste trabalho, a decisão de separação Estado - Igreja no Brasil não favoreceu uma postura radical de nenhuma das partes até mesmo porque não se muda uma cultura arraigada como a da união Estado - Igreja com um simples decreto (GOMES, 2006, p. 186).

Em linhas gerais a Pastoral combatia o divórcio entre Igreja e Estado e a liberdade de culto pois via nessas duas prorrogativas do Decreto 119-A uma afronta à doutrina católica 
(PASTORAL..., 2019). Mas, a reação que mais interessa à narrativa e que se seguiu à escrita da Pastoral foi o intenso processo de criação de dioceses pelo território nacional, ato que antes era de prerrogativa exclusiva do Imperador, mas, que com o fim do Padroado e a laicização do Estado passou a ser responsabilidade da hierarquia católica (GOMES, 2006, p. 187).

A criação de dioceses como estratégia católica para manutenção e difusão de territórios religiosos atendia também à demanda de novos agentes espaciais oriundos das classes médias urbanas, do operariado, assim como aos imigrantes desde 1888 quando a escravidão foi abolida. De acordo com Rosendahl (2012, p. 74) houve um crescimento populacional no Brasil que passou "de cerca de 14,5 milhões de habitantes em 1890 para aproximadamente 36 milhões em 1930". Será, pois, também com vistas à demanda populacional e o fortalecimento de novos espaços de convivência e trabalho oriundos de uma nascente industrialização nacional e da vida no perímetro urbano que a estratégica expansionista adotada pela Igreja Católica fará a opção pela criação da diocese de Curitiba em 1892, dois anos após as deliberações acerca do Decreto 119-A e que resultaram na escrita da Pastoral Coletiva. Fatores que foram somados à condição da religião católica vivida no Paraná e analisada por Dom Fedalto citado anteriormente.

\section{A CRIAÇÃO DA DIOCESE DE CURITIBA, 1892}

Foi no movimento da nascente autogestão por parte da Igreja Católica e da constituição do Estado Laico brasileiro que se deu a criação da diocese de Curitiba, a primeira do Paraná, em 27 de abril de 1892 pela Bula Ad Universas Orbis Ecclesias (Para as Igrejas Universais do Mundo) pelo Papa Leão XIII. Desmembrada da diocese de São Paulo (território do Paraná) e da Diocese de São Sebastião do Rio de Janeiro (território de Santa Catarina), a diocese paranaense abrangia um território com $295.485 \mathrm{~km}^{2}$, com uma população de 700 mil habitantes e 78 paróquias nos dois Estados e nove curatos no Paraná. Depois de instalada, a diocese de Curitiba passou a pertencer à arquidiocese do Rio de Janeiro até 1908 quando se tornou sufragânea da arquidiocese de São Paulo. Elevada a essa condição em sete de junho do mesmo ano teve como primeiro bispo Dom José de Camargo Barros (1858-1906), empossado somente em 1894 e tendo governado até abril de 1904 quando foi transferido pelo Papa Pio X para a diocese de São Paulo (FEDALTO, 2014, p. 145, 150, 157).

Entre 1890 e 1930 foram criadas 68 circunscrições eclesiásticas, número e progressão que contrastam amplamente com o quantidade de dioceses existentes até 1854, data da criação 
da última diocese no Império. Até 1854 havia no Brasil 12 dioceses distribuídas pelas regiões da Amazônia, pelo Nordeste e Centro-Sul configurando dessa forma, para os anos entre 1890 e 1930 um aumento de aproximadamente 566\% no número de espaços estratégicos de difusão da fé pela Igreja Católica. A dispersão diocesana no período citado privilegiou as regiões mais povoadas e mais importantes economicamente, estando o Paraná incluído dentre os bispados criados na região sul do país (ROSENDAHL, 2012, p. 75).

Nesse ínterim, o aparato estrutural desenvolvido pela Igreja Católica acabaria por se tornar um dos bastiões do próprio governo ao colaborar com o ideal de contenção e disciplinarização da sociedade brasileira notadamente a partir dos anos 1930 quando os discursos acerca dos inimigos comuns da Igreja e do Estado, leia-se fascismos, socialismos e comunismos, se fizeram ouvir com mais clareza na sociedade brasileira. Como visto, no fim do século XIX e início do XX, portanto, a Igreja buscou se organizar dentro do novo modelo governamental estabelecido e, como dito acima, criar dioceses foi uma das medidas desenvolvidas para demarcar seus espaços e domínios.

Artifício semelhante foi utilizado pela Igreja Católica europeia quando esta, na metade do século XIX, cria uma série de dioceses para compensar a perda de territórios eclesiásticos na península Itálica. Tal medida foi compreendida por Aquino (2012, p. 82) a partir do sentido certauniano de estratégia, isto é, quando "um sujeito de querer" gerencia suas relações com o exterior com base práticas marcadas por astúcias e desejos (CERTEAU, 2014, p. 44) o ainda, quando os dominadores criam os mecanismos de disciplinarização aos quais pretende submeter os consumidores (CERTEAU, 2012, p. 49), ou os considerados dominados, perpassa todo o raciocínio aqui desenvolvido.

No caso, a Igreja Católica ao decidir expandir e manter seu poder na sociedade brasileira frente o governo laico, teria se utilizado de uma estratégia. Essa estratégia, no entanto, não era original e sim, parte do fortalecimento do projeto Ultramontano levado a cabo pela Santa Sé em fins do século XIX. No caso, a Itália já havia se utilizado desse expediente que se configurou a partir da ideia de que

A diocesanização, como estratégia no sentido certauniano, foi uma das soluções encontradas pela Igreja Católica europeia, na segunda metade do século XIX, para compensar, em algumas regiões, a perda dos territórios eclesiásticos na península Itálica e em outros lugares. Efetivou-se uma territorialidade religiosa que, em princípio, tornava todo o mundo passível de 
intervenções jurisdicionais eclesiásticas. O mundo poderia ser recortado em dioceses, prefeituras, prelaturas, paróquias, etc. Desse modo, pode-se considerar que tal estratégia preservou e ampliou, no âmbito espiritual e no plano de controle religioso, os antigos domínios da Igreja, transpondo para essa nova territorialidade o capital simbólico e o poderio institucional adquirido pelo catolicismo romano ao longo de sua história milenar (AQUINO, 2012, p. 83).

Transposta para terras brasileiras a estratégia de aumento de circunscrições eclesiásticas não foi usada tanto no sentido de manutenção de espaços cujo domínio tenha sido perdido como na Itália, e sim, objetivando expandir seu poder diante do recém-constituído estado laico e ocupar ostensivamente áreas cuja distância dos centros eclesiásticos não permitiam um efetivo controle administrativo e doutrinário.

De acordo com esses acontecimentos, a criação da diocese de Curitiba faz parte do primeiro movimento de grande alcance promovido pela Igreja Católica frente às normatizações impostas pelo governo republicano no que concerne ao Paraná. Pensada a partir do exposto por Zeny Rosendahl (2012, p. 79), a criação da diocese curitibana encontra-se no tempo de difusão três em relação à diocese Primaz de Salvador que data de 1551 como se pode verificar na Figura 1 sendo precedida pelas dioceses do Rio de Janeiro, 1676 e São Paulo, 1745.

Figura 1: Criação da diocese de Curitiba no quadro da difusão eclesiástica a partir de $1551^{4}$.

\footnotetext{
${ }^{4}$ Quadro elaborado sobretudo a partir das obras de ROSENDAHL, 2012 e FEDALTO, 2014.
} 


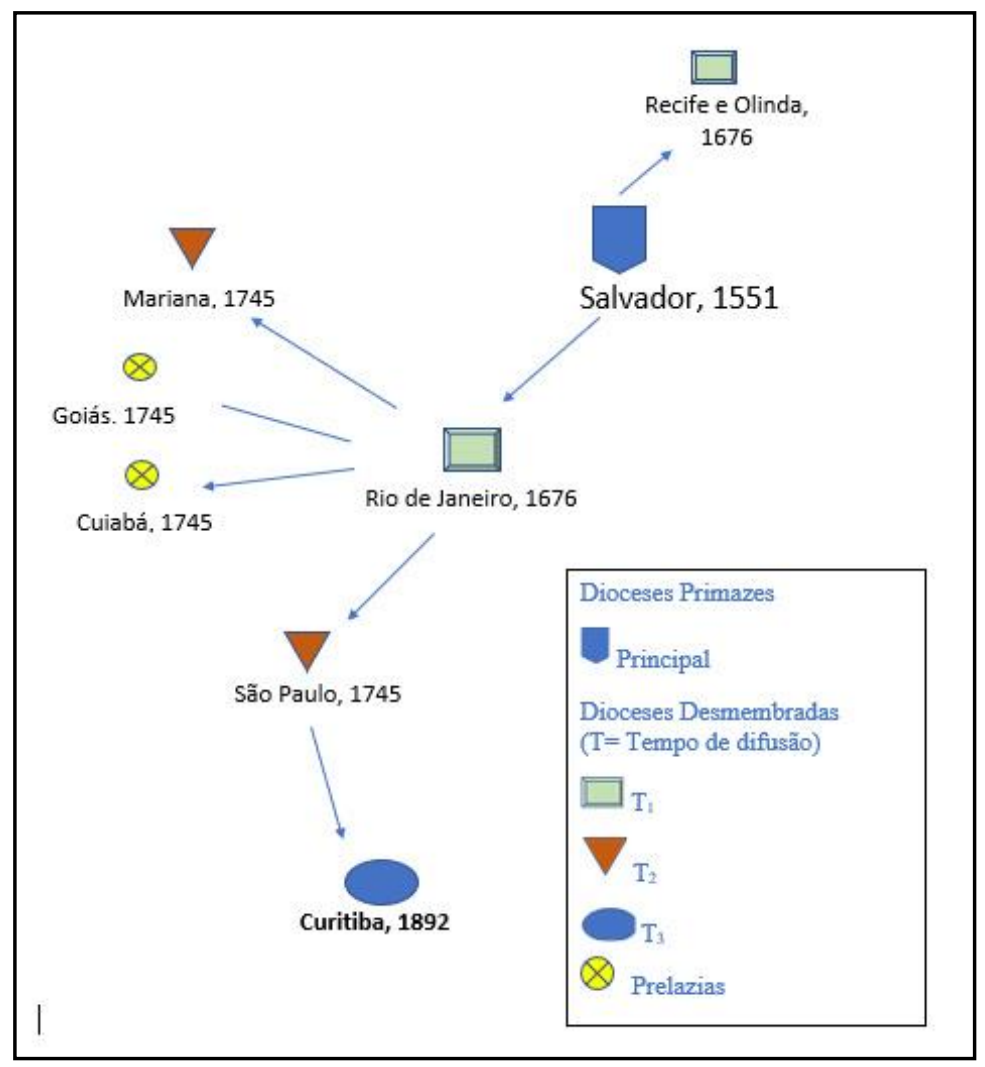

Fonte: A própria autora.

Com a intensão sistemática de laicizar governo e sociedade em fins do XIX e início do XX, há uma ruptura sútil na relação entre governo e igreja num Brasil que se propõe republicano. Com isso, a Igreja Católica passa a ter maior autonomia frente a seus próprios negócios e estatutos. Consciente do fato de que as dioceses existentes não eram capazes de atender de forma adequada a população foram agendadas discussões, avaliações e conferências para escolher a melhor estratégia para ampliar a cobertura territorial, material, espiritual e territorialista da Igreja Católica dentro do imenso país em que estava inserida como visto em páginas anteriores por ocasião do estudo acerca do Decreto 119-A e da reação da Igreja Católica ao documento.

\section{CONSIDERAÇÕES FINAIS}

Zeny Rosendahl (2012) ao estudar a constituição do espaço religioso no Brasil desde 1500 até o estabelecimento do Império considera que a ocupação se deu em saltos cujos espaços percorridos são de maior ou menor alcance temporal. Considerando essa prerrogativa, observase que durante os anos de 1801 e 1900 houveram poucos investimentos na fundação de dioceses 
sendo citadas pela autora a existência de dez dioceses para atender a toda população do Império por exemplo (ROSENDAHL, 2005, 12938). Como visto acima, o significativo aumento de circunscrições eclesiásticas após o fim do Padroado é um dos sintomas da autogestão católica e, segundo Miceli a "estadualização" levada a cabo pelo Estado laico acabou por promover praticamente todas as capitais do país à condição de sedes episcopais.

As tendências descentralizadoras do regime republicano, ou melhor, os padrões de controle político associados à vigência da política dos governadores, a montagem dos partidos republicanos nos diversos estados, e a autonomia considerável de que passaram a dispor os clãs oligárquicos em âmbito local e regional favoreceram sem dúvida o processo de "estadualização" das políticas implementadas pelos detentores do poder eclesiástico. Todas as capitais estaduais foram promovidas a sedes de dioceses para cuja gestão foram muitas vezes convocados elementos do clero pertencentes a importantes grupos oligárquicos. $\mathrm{O}$ acesso e a familiaridade de trânsito junto a esses círculos constituem trunfos indispensáveis ao levantamento de recursos nas proporções exigidas pelo vulto das despesas necessárias à formação do patrimônio diocesano (MICELI, 1985, p. 44).

A criação da diocese de Curitiba, vista sob essa perspectiva, extrapola os motivos comumente citados para a criação de dioceses como o aumento no número de habitantes oriundo da expansão territorial e, consequentemente a dificuldade de atendido aos fiéis exatamente pela abrangência física e humana de uma diocese e insere o evento como resultante direto das mudanças e da reorganização do clericato brasileiro durante o primeiro movimento promovido logo após a separação entre Estado e Igreja em 1889. Nessa perspectiva, considerase a instalação da diocese na cidade de Curitiba no ano de 1892 como um movimento complexo de interação entre a estratégia de estabelecimento de um estado que se propôs isento em relação à religião no Brasil e a estratégia espacial criada pela igreja católica para expandir a instituição e renovar a presença eclesiástica numa sociedade recém organizada sobre a laicidade.

Três anos após a Proclamação da República e dois anos após a publicação do Decreto 119-A e de sua réplica católica, a Pastoral Coletiva, a criação da diocese curitibana é compreendida nesse artigo como fruto da estratégia para expansão de domínios territoriais e simbólicos elaborado pela Igreja Católica leva a cabo por meio do aumento no número de dioceses pelo país. Com essa medida, acreditava a elite eclesiástica fazer frente ao movimento modernizante promovido pelo governo republicano no que concerne a equiparação entre a 
religião católica e as demais religiões proposto pelo Decreto 119-A e também reforçar seu poder no país por meio da constituição de áreas sob o domínio como dioceses, paróquias, escolas, casas de misericórdia, seminários, grupos de leigos católicos, dentre outras.

\section{REFERÊNCIAS}

AQUINO, M. de. A Igreja Católica na Primeira República Brasileira (1889-1930): laicidade pragmática, diocesanização, congregações religiosas. In: CARREIRO, Gamaliel Silva; SANTOS, L. de A.; FERRETTI, S. F.; SANTOS, T. L. de. (Orgs.). Todas as águas vão para o mar: poder, cultura e devoção nas religiões. São Luiz: EDUFMA, 2013. p. 113-142

AQUINO, M. de. Modernidade republicana e diocesanização do catolicismo no Brasil: a construção do bispado de Botucatu no sertão paulista (1980-1923). 2012. $301 \mathrm{f}$. Tese. Faculdade de Ciências e Letras de Assis - Universidade Estadual Paulista. Assis, SP.

ARQUIDIOCESE DE SÃO PAULO. Disponível em < http://www.arquisp.org.br/historia/dos-bispos-e-arcebispos/bispos-diocesanos/dom-linodeodato-rodrigues-de-carvalho >. Acesso em 23 jan. 2019.

BRASIL. DECRETO 119-A, DE 07 DE JANEIRO DE 1890. Rio de Janeiro, RJ, jan. 1890. Disponível em < http://www.planalto.gov.br/ccivil_03/decreto/1851-1899/D119-A.htm>. Acesso em 29 jan. de 2019.

CERTEAU, M. de. A Invenção do cotidiano. 22. ed. Petrópolis, RJ: Vozes, 2014.vol 1. CERTEAU, M. de. El lugar del otro: historia religiosa y mística. Buenos Aires, Argentina: 2007.

FEDALTO, P. A. M. (Dom). História da Igreja no Paraná: contribuição de Dom Pedro Antônio Marchetti Fedalto para a celebração do Jubileu de Ouro do Regional Sul 2 da CNBB. Curitiba: Serzegraf Indústria e Editora Gráfica Ltda, 2014. 588 p.

GOMES, E. da S. A separação Estado-Igreja no Brasil (1890): uma análise da pastoral coletiva do episcopado brasileiro ao Marechal Deodoro da Fonseca. 2006. $242 \mathrm{f}$. Dissertação (Mestrado em Teologia Dogmática). Centro Universitário Assunção - Pontifícia Universidade de Teologia Nossa Senhora da Assunção. São Paulo. Disponível em < http://livros01.livrosgratis.com.br/cp023647.pdf> . Acesso 29 jan. 2019.

MICELI, S. P. de B. A elite eclesiástica brasileira (1890-1930). 1985. 233 f. Tese Departamento de Ciências Sociais do Instituto de Filosofia e Ciências Humanas na Universidade Estadual de Campinas, Campinas-SP.

MOURA, O. (Dom). Ideias católicas no Brasil: direções do pensamento católico do Brasil no século XX. São Paulo: Convívio, 1978.

PASTORAL COLETIVA DO EPISCOPADO BRASILEIRO CONTRA A LIBERDADE RELIGIOSA. Disponível em: https://permanencia.org.br/drupal/node/1327. Acesso em: 31 mar. De 2019.

ROSENDAHL, Z. Primeiro a obrigação, depois a devoção: estratégias espaciais da Igreja Católica no Brasil de 1500 a 2005. Rio de Janeiro: EdUERJ, 2012. 196 p. 
VITAL, D. L. Iluminismo e revolução nas ideias e nas práticas políticas da "ilustração" brasileira. 2015. 219 f. Dissertação (Mestrado) Universidade Federal de Juiz de Fora, Instituto de Ciências Humanas. Programa de Pós-Graduação em História, Juiz de Fora-MG. 